\title{
THE EXPORT PERFORMANCE OF INDONESIAN CANNED SKIPJACK IN WORLD MARKET
}

\author{
Erlangga Esa Buana ${ }^{1,2 *}$, Wen-Chi Huang ${ }^{2}$, Nuhfil Hanani $\mathbf{A R}^{3}$ \\ 1) Master's Degree in Agricultural Economics, Post Graduate Program Faculty of Agriculture, University of \\ Brawijaya, Indonesia \\ 2) International Master's Degree Program in Agribusiness Management, National Pingtung University of Science \\ and Technology, Taiwan \\ ${ }^{3)}$ Lecturer, Agricultural Economics, University of Brawijaya, Indonesia
}

*Corresponding author: erlanggaesa@gmail.com

\begin{abstract}
Tuna (skipjack) is one of the major exporting fishery commodities for Indonesia only second to shrimp and crab. Although tuna is exported in various forms, the canned tuna enjoys the highest export value. Indonesia contributes to $16 \%$ of the global tuna supply, and $70 \%$ of Indonesian tuna is exported. Indonesia is one of the most significant tuna producers in the world. This study investigated the growth in export of Indonesian canned skipjack. The Market Share Index (MSI) and The Constant Market Share (CMS) was used to measure the growth export of Indonesian canned skipjack. Based on results of Market Share Index show Indonesia took the second place in Japan market, better than its performance in the United States and United Kingdom market. The result from Constant Market Share showed that competitiveness, commodity composition and growth effect affected canned tuna export in the world market. But, Indonesia also had fluctuation performance but in generally tendency was stable.
\end{abstract}

Keywords: Canned Skipjack, Indonesia, MSI, CMS, World Market

\section{INTRODUCTION}

Located between Indian and Western and Central Pacific Oceans (WCPO), Indonesia is an archipelago country, with the fourth longest coastline in the world. The Western and Central Pacific Ocean (WPCO) has incredible amount of tuna. In 2010 it provided 59\% of global tuna supply (SPC, 2010).

The

potential of Indonesian fisheries value is estimated to be US\$ 82 billion, including from marine capture as US\$ 15.1 billion. Tuna is one of the essential commodity for the fisheries sector in Indonesia. The export value is only second to shrimp and crab. Tuna is a migratory species, and approximately $40 \%$ of world production is from high seas.

According to Sunoko and Huang (2014), the tuna industry made a significant contribution to Indonesian and world. Almost $16 \%$ of the global tuna supply is from Indonesia; $70 \%$ of Indonesian tuna was exported, and $30 \%$ is consumed

Agricultural Socio-Economics Journal domestically. The importance of the fisheries sector to the Indonesia economy is not an issue.

The industry plays a vital role in the Indonesia economy, contributing around 3\% of national GDP in 2012. According to Kusumastanto et al. (2016), the airtight container skipjack (HS 160414) contributed the highest product each year compared with fresh tuna (HS 0302) and frozen tuna (HS 0303). In 2014, the total contribution of the skipjack production nationwide was more than fifty percent (64.07\%) (FAO, 2017). Indonesia was among the top five exporters of canned tuna to the global market. The primary importers of canned tuna cover Japan, United Kingdom, and the United States.

Therefore, this study was conducted to analyze competitiveness of canned tuna in the global market and to know the Indonesia position to compete with another major player countries in the world market for canned tuna industry.

\section{RESEARCH METHODS}

The analysis method of this study used market share index to figure out how Indonesia canned tuna 
market condition in main export destination country and constant market share order to study the relation between structural changes in world trade and to determinant the export and growth performance of individual countries (Fagerberg and Gunnar Soll E, 1985).

$$
\begin{aligned}
& \text { MSI }_{j}=\frac{\text { Canned Tuna }_{E x}(\mathrm{I}),(\mathrm{P}),(\mathrm{M}),(\mathrm{T})}{\text { Canned }^{\operatorname{Tuna}} \mathrm{IM}_{\mathrm{M}}(\mathrm{J}),(\mathrm{US}),(\mathrm{UK})} \\
& \mathrm{V}^{\prime} . .-\mathrm{V}_{. .} \equiv \sum_{\mathrm{i}} \mathrm{r}_{\mathrm{i}} \mathrm{V}_{\mathrm{i} .}+\sum_{\mathrm{i}}\left(\mathrm{V}_{\mathrm{i} .}^{\prime}-\mathrm{V}_{\mathrm{i} .}-\mathrm{r}_{\mathrm{i}} \mathrm{V}_{\mathrm{i} .}\right) \\
& \equiv(\mathrm{rV} . .)+\sum_{\mathrm{i}}\left(\mathrm{r}_{\mathrm{i}}-\mathrm{r}\right) \mathrm{V}_{\mathrm{i} .}+\sum_{\mathrm{i}}\left(\mathrm{V}_{\mathrm{i} .}^{\prime}-\mathrm{V}_{\mathrm{i} .}-\mathrm{r}_{\mathrm{i}} \mathrm{V}_{\mathrm{i} .}\right)
\end{aligned}
$$$$
\text { (a) }
$$

(c)

This equation represents for the "two-level" analysis in which the growth of country an export device into part attributed to:

a) The general rise in world exports.

b) The commodity composition of $i$ exports in Period 1. It measures whether the country or state in the period 1 more focused on commodities that grew relatively fast or slowly between of period 1 and period 2 . If the value is positive, that means the country has concentrated its export on the commodities with growth rates are higher than the world average and vice versa.

c) unexplained residual (competitiveness effect) show the difference between $i$ actual export increase and the hypothetical increase if $i$ had maintained its share of the exports of each commodity group. If the value is negative, that means country has unsuccessful to maintain the market share in all markets for commodity (competitiveness has decreased). If the value is positive, that means the country increased the market shares in all markets for commodity (competitiveness has increased).

\section{RESULTS AND DISCUSSION}

Market Share Index (MSI) aims to figure out how the Indonesian canned tuna market conditions in primary export destination country compared to the others competitor that exporting in the same destination. This study uses annual calculation sin 1996 to 2016 for other major player in exported country for canned skipjack, which is Thailand, Philippines and Mauritius as competitor of Indonesia.

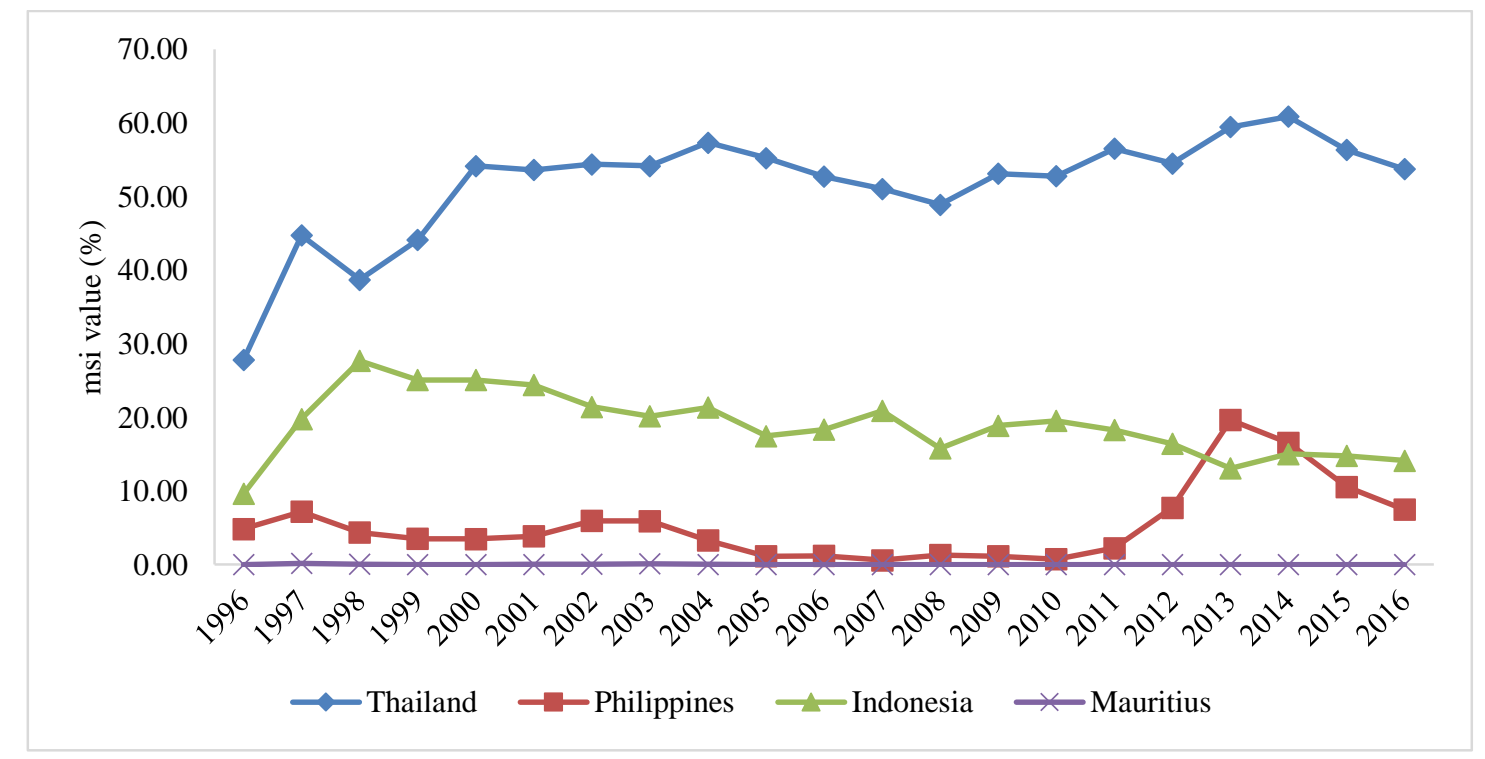

Figure 1. Comparison of MSI in Japan Market

Figure 6, shows that in Japan market, from the year 1996 until 2016, Thailand export to Japan took the most significant market share. Best market to export Thailand canned tuna is Japan and Thailand has the first position in Japan market. Although Thailand MSI value fluctuated, still get the first position in this market. Indonesia took the secondplace position after Thailand in Japan market.
Indonesia average value is $19 \%$ of canned tuna market in Japan. Indonesia already did an export of canned tuna by US\$ 783 million in 1996 until 2016, with the average US\$ 71 million.

Indonesia always got the second position after Thailand, the reason of decreased Indonesia MSI value caused by the fluctuation of production and export value canned tuna from Indonesia to Japan, 
the consistently of export in the year, and the total import of canned tuna in the market.

The third position is the Philippines with an average market share of 5\% in Japan market. The Philippines exported of canned tuna by US\$ 274 million from 1996 until 2016, with average US\$ 24 million. The export value show, the Philippines in the third position in Japan market, after Thailand and Indonesia. Moreover, Japan is the most significant importer of Indonesia tuna, the Philippines is still not dominating in the market trade. Japan is not the first destination of Philippines exporting.

Japan has a vast potential market for Indonesian canned tuna. Based report from MMAF Indonesia, from 2010 Japan did export canned tuna from Indonesia. The request for canned tuna from Japan consumed because of consumption fish in Japan very high, so Japan needed tuna or canned tuna to fulfilled demand. on sustainability finishing to keep the stock of Indonesia tuna.

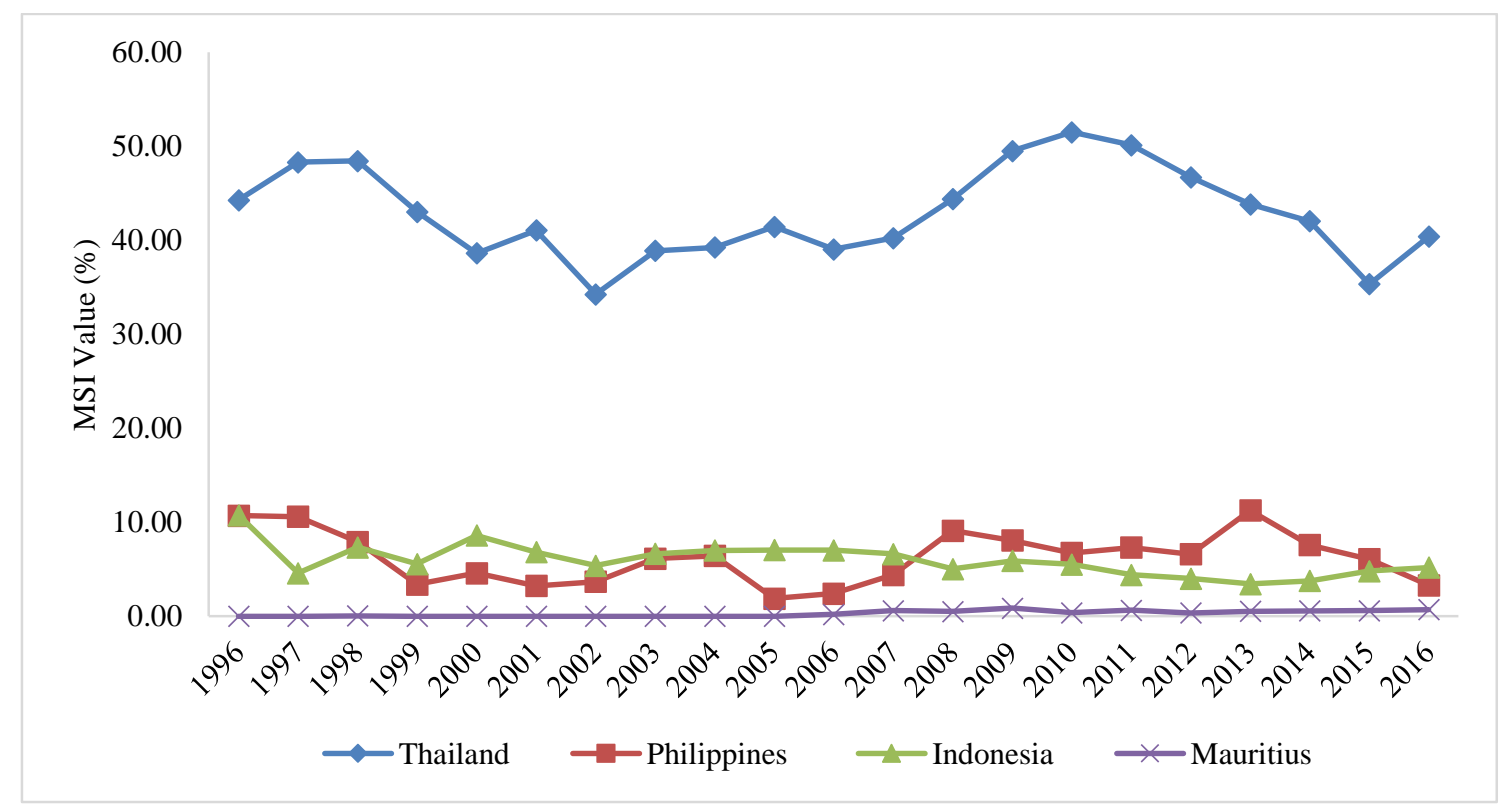

Figure 2. Comparison of MSI in United States Market

Figure 2, it shows that in United States market, since the year 1996 until 2016, Thailand took the most significant percentage of proportion among all exporter countries. Thailand did a lot of export canned tuna to the United States, with the total of export value US\$ 6,624 million from the year 1996 until 2016 and the average value US\$ 315 million.

The export value of canned tuna, Thailand can dominate average $43 \%$ of United States market. From the amount, can recognize that United States market is the best market for Thailand canned tuna and have the first position in the United States. Although the value of MSI Thailand fluctuates, this country still in the early place in this market.

After Thailand, Indonesia took the second position in United States market, Indonesia dominated around $6 \%$ of canned tuna market in the United States. Although the United States is the second highest importer of canned tuna from Indonesia, Indonesia still did not take the first position in the United States market. The third view, there is the Philippines with average percentage $6 \%$ same result with Indonesia in United States market.

The Philippines in the third place in the United States market, after Thailand and Indonesia. This decrease might be happening since the Philippines difficult for getting a supply of tuna in the ocean, so that affected export value from Philippines and quantity of tuna decreased in United States market.

In period 1997, Indonesia did not survive in the United States market. That period was happening Global Economic Crisis in the world could be the reason for falling value of canned tuna in Indonesia. The time of 2005 Philippines did not survey and got the lowest value after Mauritius. The MSI value Thailand in United States market was the highest.

The last position in the United States took by Mauritius country with the lowest value in the United States market. The total export value of Mauritius to the United States is about 54.9 million US\$ from the year 1998, 2006 until 2016. Mauritius 
did not export tuna in the following years 1996 to 2005.

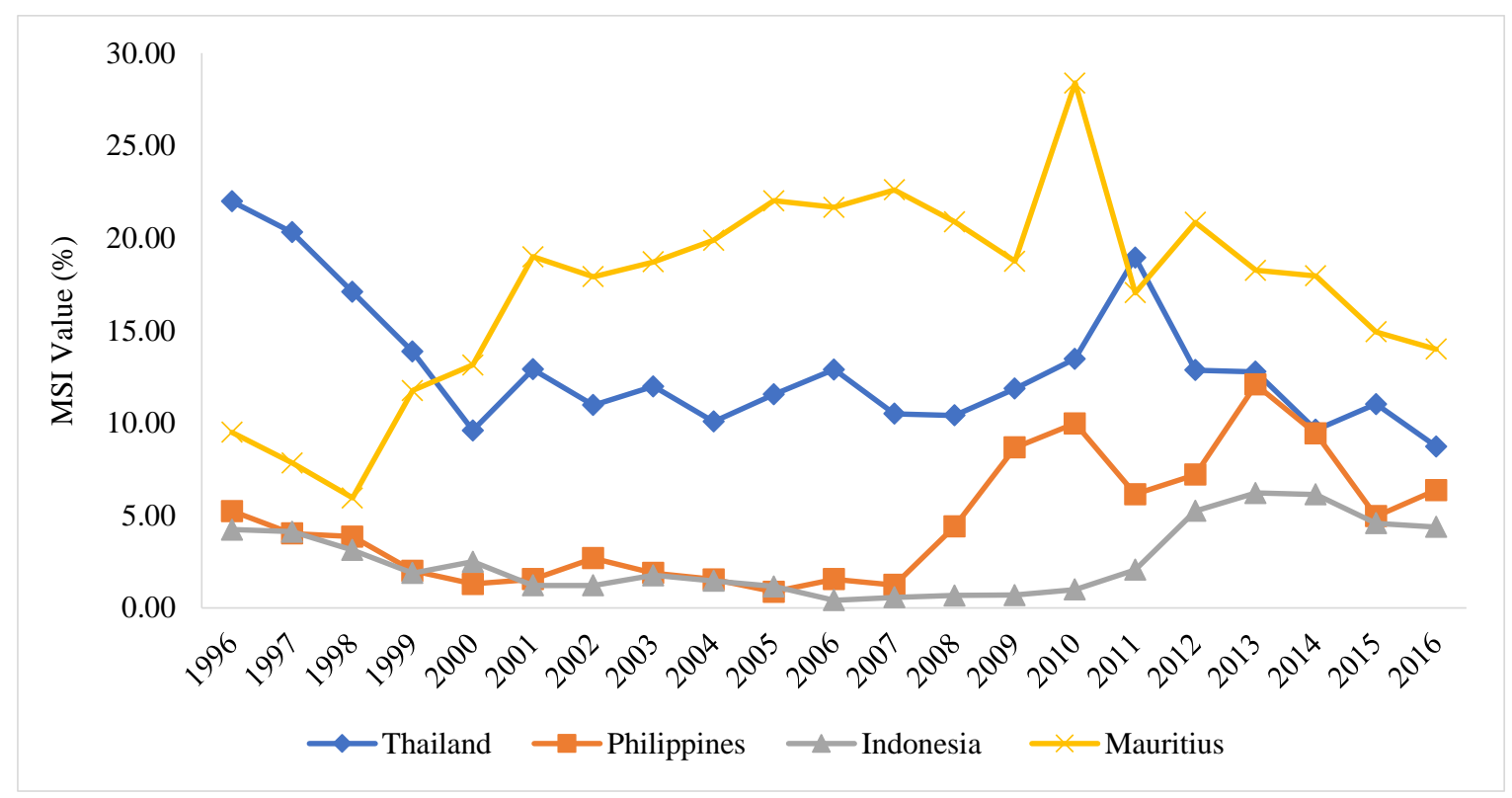

Figure 3. Comparison of MSI in United Kingdom Market

Based on figure 3, Indonesia was the lowest value in the United Kingdom market. This percentage is the most economical in United Kingdom market, so that is can concluded that Indonesia did little export to United Kingdom market. The total value of exported canned tuna to the United Kingdom is US\$ 235 million with the average US\$ 11.19 million by the year 1996 until 2016. The United Kingdom is the lowest market that imported canned tuna from Indonesia, in this market Mauritius is the most significant value among another exporter countries.

The first position of the highest country exporter is Mauritius. Mauritius did export to United Kingdom Market from the year 1996 until 2016. United Kingdom market is the priority market for Mauritius. Based on figure 6, the MSI values of Mauritius fluctuated and remarkably decreased in 1998 because global economic crisis and surprising increased in 2010, after the global economic turmoil.

The third highest country exporter is the Philippines with the percentage 5\% and export value US\$ 439.41 million with average value US\$ 20.92 million. Philippines has fluctuated MSI value since the year 1996 until 2016. The reason the Philippines is the third exporter because the Philippines have another target of market trade.
The last position in country exporter in United Kingdom with the average percentage of MSI value 3\% in Indonesia. Indonesia did an export of canned tuna to the United Kingdom from the year 1996 until 2016 with the lowest amount than other competitor countries. This condition caused by import rules in the United Kingdom tighter and policy from the United Kingdom, the position of Indonesia in this market becomes the lowest among the top four exporters.

Constant Market Share (CMS) Figure 4 shows the export changes in Indonesia, Thailand, Philippines, and Mauritius during 1996 to 2016. The trend of export changes all states had fluctuated during the period. Indonesia also had fluctuation performance but in generally tendency was stable. The highest export value for Indonesia on 2011, during that time, was after global crisis effect and all countries trend was better, so they can improve the export of canned tuna from Indonesia. However, different condition with Thailand that had extremely fluctuated, the extremely change of export value on canned tuna in 2015 might was caused by nature condition of fishing tuna, directly affected the production on that period.

Philippines had decreasing in change of export value canned tuna in 2014. That might 
be happen was caused by nature condition of fishing tuna, directly affected the production and export value on that period.

The growth effect in figure 5 shows there is fluctuating movement during the period 1996 to 2016. Different condition with export change (figure 4) in 2009 during global financial crisis, the growth effect of all countries have negative value, that measures the growth of canned tuna have negative to the overall rise in world exports. In 2010, after global financial crisis four countries have increasing into positive value, which means on this period the growth of canned tuna had positive value attribute into overall rise in world exports.

However, on the other period $2013-2014$ to 2015 - 2016, the growth effect of four countries did not stay constant. Although in 2013 - 2014 the growth effect value were positive, in period 2015 - 2016 drop into negative. This condition might have caused by condition after global crisis, the total import all commodities in the world decreased during period (UN Comtrade, 2017).

The Commodity composition effect of all exporter countries shows in figure 6 in 2009 during global financial crisis, four countries had positive value of canned tuna; however, in
2010 all countries had negative value. The positive value means countries had concentrated in export on commodity of canned tuna reason is because the growth rate of canned tuna is higher than the world average. This condition can be concluded canned tuna had survived several years after global financial crisis. The period $2014-2015$, the commodity composition effect of canned tuna had decreasing tendency, its measures the concentrated export of canned tuna had low growth rate than the world average.

The figure 7 was the competitiveness effect was indicated the performance of the country into maintaining its share of the exports of canned tuna. During period 1996 - 2016, the four countries had fluctuated value in competitiveness affect. The competitiveness effect shows, between four countries, competitiveness effect of Indonesia had fluctuated tendency in constant value, its meaning Indonesia can maintain market share in all market for canned tuna. Different situation shows between Thailand it has extremely fluctuated value, following Philippines and Mauritius, which indicating those countries failed to maintain market share on canned tuna commodity.

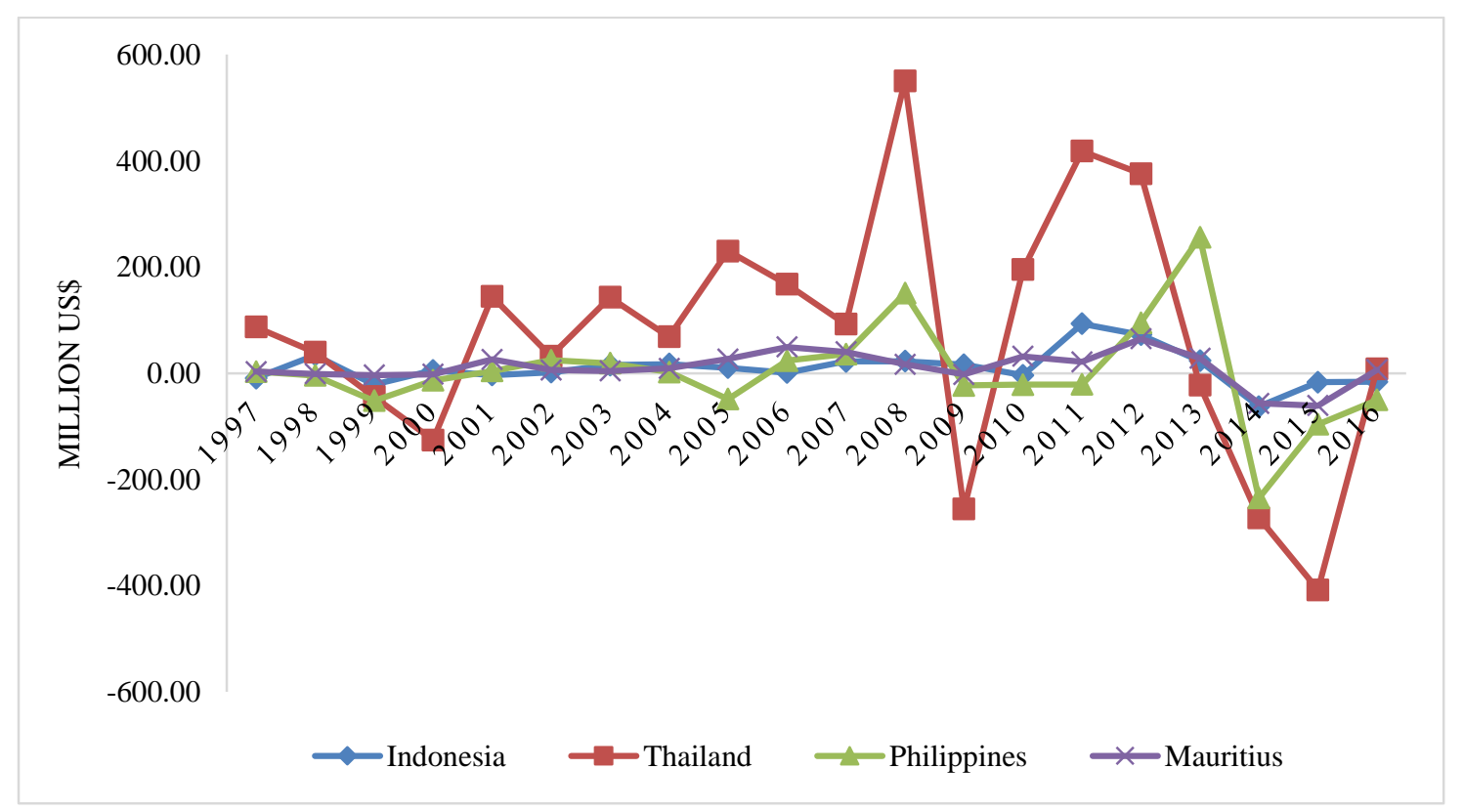

Figure 4. Annual Export Changes in Canned Skipjack. 


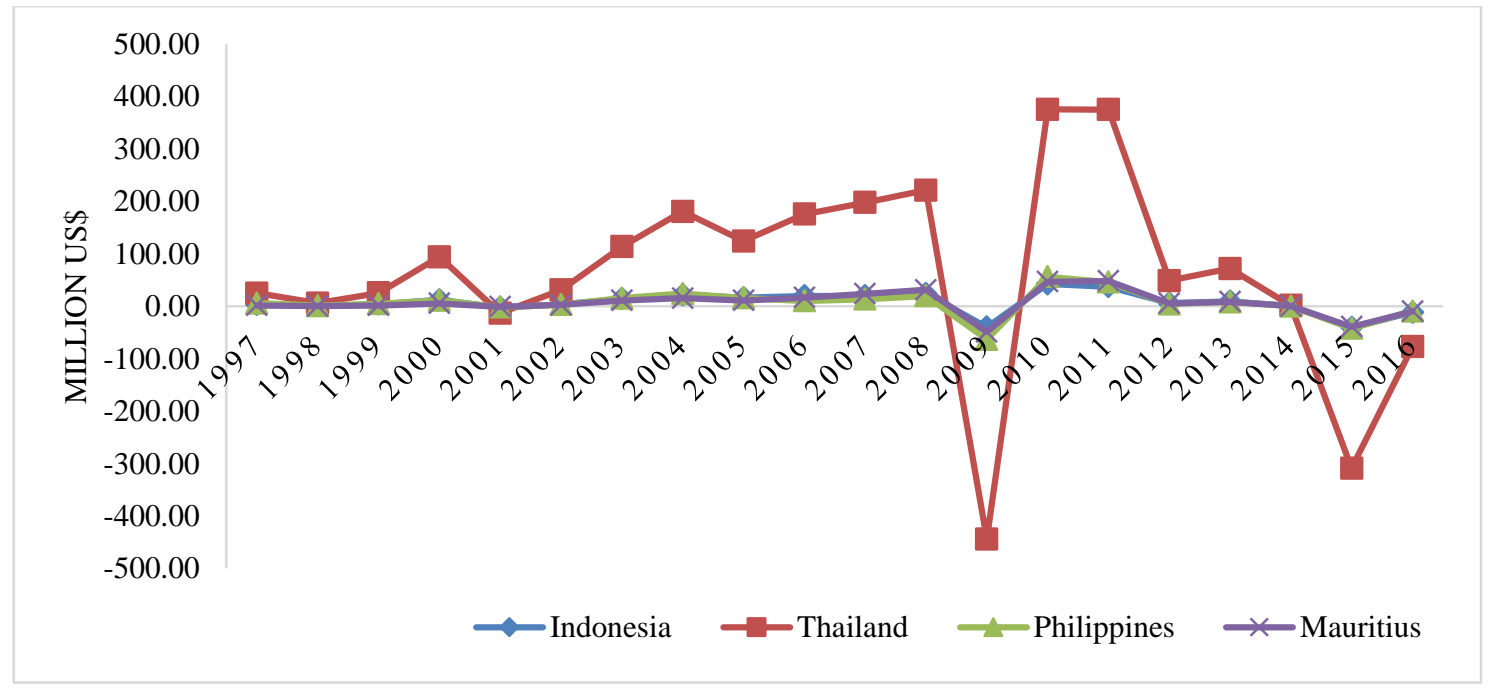

Figure 5. Growth Effect in Canned Skipjack for CMS

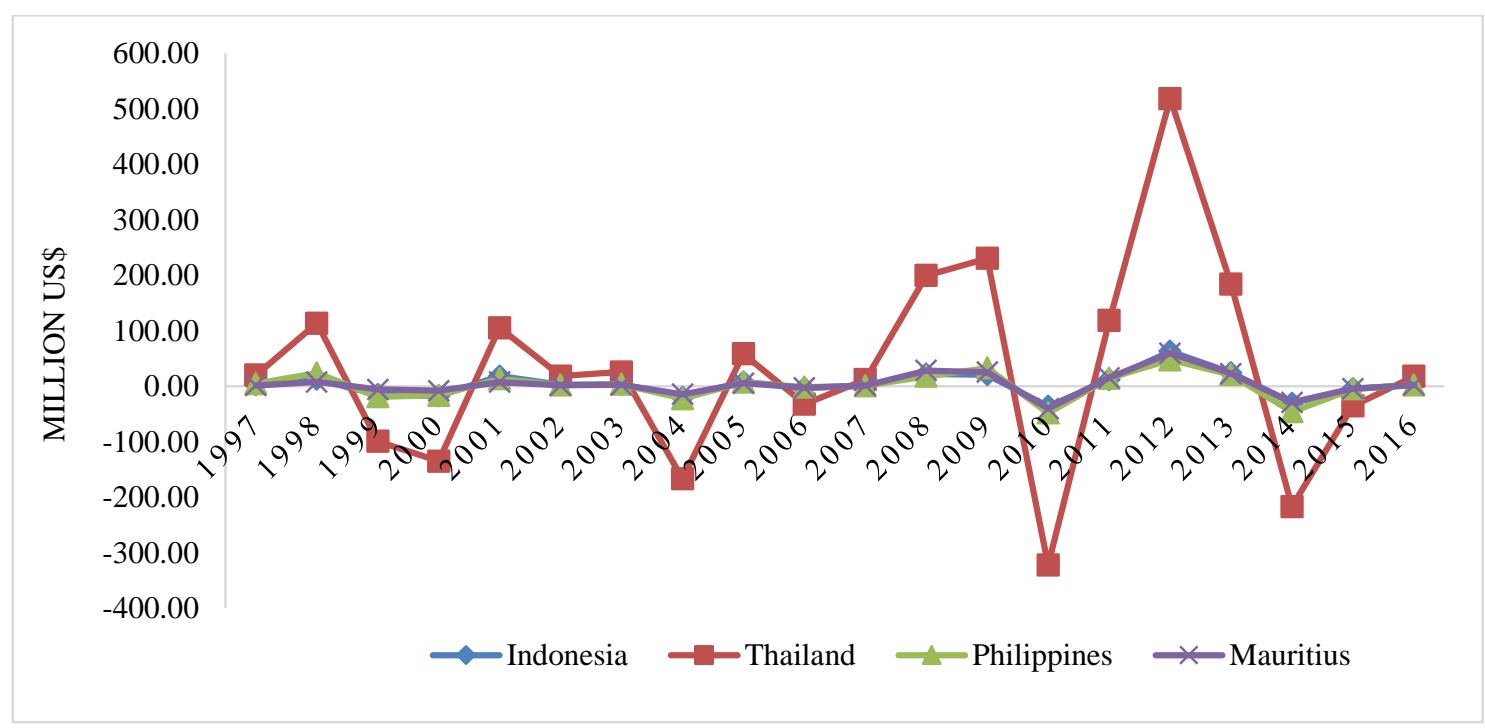

Figure 6. Commodity Composition Effect in Canned Skipjack for CMS

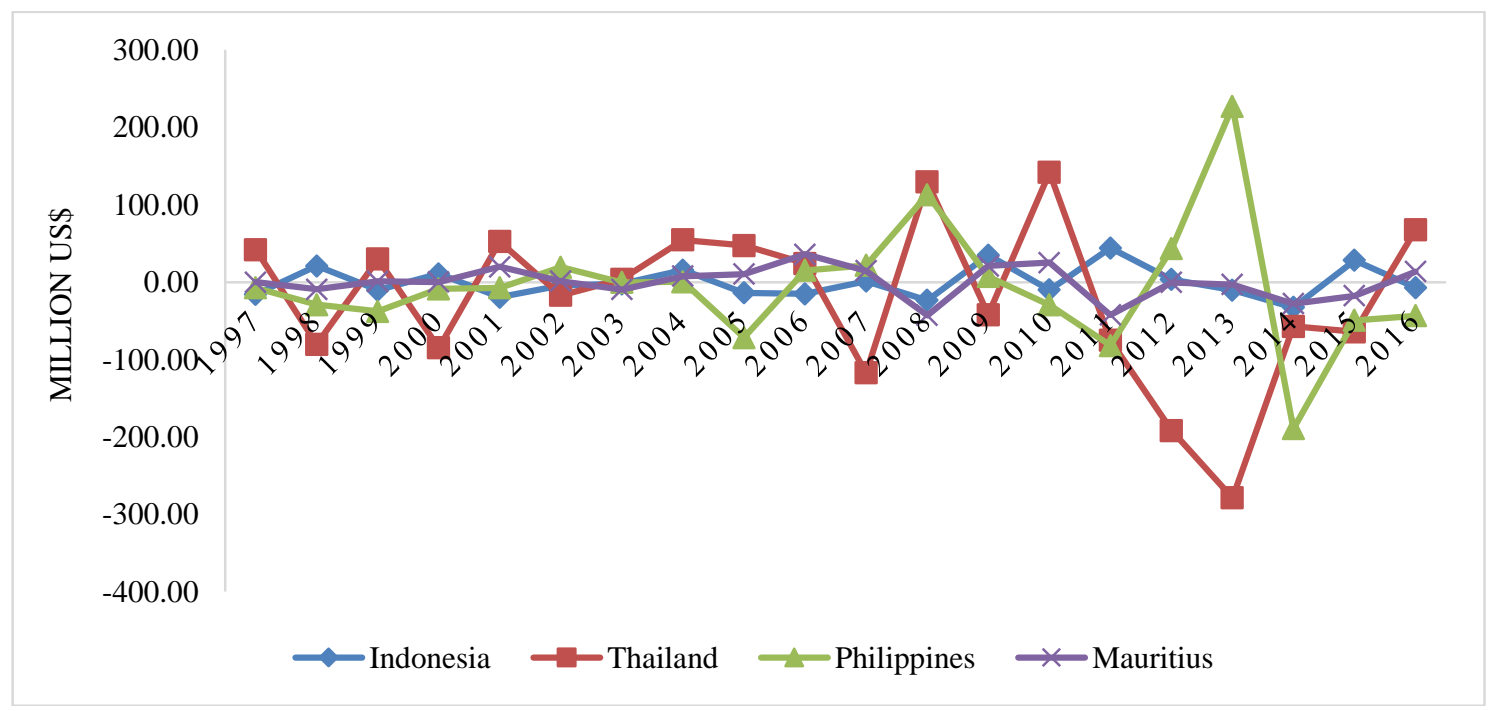

Figure 7. Competitiveness Effect in Canned Skipjack for CMS 


\section{CONCLUSION}

The Market Share Index (MSI) result shows that Indonesia has the second position after Thailand in Japan Market from the year 1996 - 2016. The United States market, Indonesia takes second and third between the Philippines, and Thailand took the first position. In the United Kingdom market, Mauritius took the first place and Indonesia in the last rank place.

The Constant Market Share analyses show that in the period 2009, the global economic crisis that affected all exporter countries. This condition caused by the decline of growth effect value and the decline in export performance. In period 2010 to 2013, Indonesia, Thailand, Mauritius have positive value in export changes. The competitiveness effect still big problem for all countries, in this case, Indonesia has tendency to keep competitiveness effect.

\section{ACKNOWLEDGEMENTS}

My greatest appreciation and gratitude for all my advisors; Professor Wen-Chi Huang, Ph.D., and Professor Nuhfil Hanani, for their patience, guidance, and dedication for this study. Also, my deeply gratitude for Hsing-Hua Chang, Ph.D. for suggestions and support.

\section{REFERENCES}

SPC. 2010. Western and Central Pacific Fisheries Commission Tuna Fishery Yearbook. Technical Report. Secretariat of the Pacific Community.

Sunoko, R., and H-W Huang. 2014. Indonesia Tuna Fisheries Development and Future Strategy. Marine Policy 43:174-183.

Kusumastanto, T., L. Adrianto, and A. Fahrudin. 2016. Tuna industries competitiveness in international market. Case of Indonesia. Aquaculture, Aquarium, Conservation and Legislation-International Journal of the Bioflux Society (AACL Bioflux), 9(6).

Fagerberg, Jan and S. E. Gunnar 1985. The Method Of Constant-Market Shares Analysis Revisi Ted. Discussion Paper Central Bureau Of Statistics, 9: 1-5.

Food and Agriculture Organization (FAO). 2017, GLOBEFISH - Analysis, and Information on world fish trade. Accessed from http://www.fao.org/inction/globefish/market-reports/en/ 